\title{
The Vagabond Mind: Depression and the Medieval Anchorite
}

\author{
Professional affiliation and e-mail address: \\ University of Oxford, Hertford College \\ ayoush.lazikani@ell.ox.ac.uk / ayoush.lazikani@hertford.ox.ac.uk
}

\begin{abstract}
:
There has as yet been no sustained scholarship on anchoritic 'depression' in the High Middle Ages. Situated in burgeoning research on the interplay between literature and medicine, the present article seeks to address this gap. It examines the attempts of authors and readers to define, express, and ultimately soothe depressive and despairing states through the act of reading. Focus will rest on three anchoritic guidance texts from the eleventh to thirteenth centuries: Goscelin of Saint-Bertin's (c. 1035-1107) Latin Liber confortatorius; Aelred of Rievaulx's (1110-1167) Latin De institutione inclusarum; and the English Ancrene Wisse (1215-1230). For anchorites, the practice of reading these texts heals and rejuvenates a wearied soul - or, as put by Goscelin, the vagabond mind ('mente uagabunda')
\end{abstract}

Keywords:

anchoritism, medicine, depression, Middle English, medieval Latin, Anglo-Norman

Despair, sadness, and spiritual weariness affected medieval readers deeply especially those embracing the specialized anchoritic life. The author of Ancrene Wisse, a thirteenth-century anchoritic guide in English, advises his readers against making a vow to a rule of outer observance, since any failure would instigate 'unhope' (despair): the negation of healthy trust in God's mercy. ${ }^{1}$ Indeed, from the earliest recorded cases of the vocation, anchorites are said to be at high risk of despair

\footnotetext{
${ }^{1}$ Ancrene Wisse, ed. by Millett, 2 Vols, I, p. 3; all subsequent references are to this edition. I am very grateful to Dr Annie Sutherland and the anonymous reviewer of this article for their valuable feedback.
} 
born from spiritual depression, 'the disease par excellence of the hermit'. ${ }^{2}$ Healing this condition is thus a major concern for authors of guidance texts, but there has as yet been no sustained scholarship on anchoritic depression in the High Middle Ages. Situated in burgeoning research on the interplay between literature and medicine, the present article seeks to address this gap. ${ }^{3}$ It examines the attempts of authors and readers to define, express, and ultimately soothe depressive and despairing states through the act of reading. Focus will rest on three anchoritic guidance texts from the eleventh to thirteenth centuries: Goscelin of Saint-Bertin’s (c. 1035-1107) Latin Liber confortatorius; Aelred of Rievaulx’s (1110-1167) Latin De institutione inclusarum; and the English Ancrene Wisse (1215-1230). ${ }^{4}$ For anchorites, the practice of reading these texts heals and rejuvenates a wearied soul - or, as put by Goscelin, the vagabond mind ('mente uagabunda'). ${ }^{5}$

\section{The Depressive Spectrum}

\footnotetext{
2 Toohey, Melancholy, Love, and Time: Boundaries of the Self in Ancient Literature, p. 138.

${ }^{3}$ See especially two collections of essays: Medicine, Religion, and Gender in Medieval Culture, ed. by Yoshikawa, and Medieval and Early Modern Literature, Science and Medicine, ed. by Falconer and Renevey.

${ }^{4}$ On the dating of Ancrene Wisse, see Ancrene Wisse, ed. by Millett, II, pp. xi-xiii; and Dolan, 'The Date of Ancrene Wisse', pp. 322-323.

5 'The Liber confortatorius', ed. by Talbot, p. 69; all subsequent references are to this edition.
} 
Flourishing scholarship on the anchoritic life over the past three decades has enabled research into ‘anchoritic depression' in two key ways. First, long-standing and more recent work has revealed the sensitivity of anchoritic reading practices - the ruminative lectio of the solitary life, which, as will be seen, can heal a depressed soul. ${ }^{6}$ Secondly, scholars have unearthed the vexed interplay between the anchorite's body, the anchorite's soul, and the cell in which both dwelled; as will also be seen, the anchorite's enclosure is central to the authors' explorations of depressive states. ${ }^{7}$ Beyond scholarship on anchoritism, a materialist sensitivity to depressive conditions has also been enabled by Siegfried Wenzel’s 1967 study on acedia from early Christian history to the later Middle Ages, and by Alexander Murray's two-volume work on medieval suicide (1998). Murray’s work has since been developed by Rebecca McNamara, among others. ${ }^{8}$

Scholarship on anchoritic depression is weighted with terminological difficulties. Use of the noun ‘depression’ risks anachronistic and crudely pathologized readings. ${ }^{9}$ Mindful of this risk, translators and editors of anchoritic guidance texts

\footnotetext{
${ }^{6}$ See especially Gunn, Ancrene Wisse; Innes-Parker, 'Ancrene Wisse and De Wohunge of Ure Lauerd'; Millett, 'Women in No Man’s Land'; Mulder-Bakker, Lives of the Anchoresses, trans. by Scholz; and Robertson, “"This Living Hand”'.

${ }^{7}$ See especially Georgianna, The Solitary Self; Anchorites, Wombs and Tombs, ed. by McAvoy and Hughes-Edwards; and McAvoy, Medieval Anchoritisms.

${ }^{8}$ McNamara, 'The Sorrow of Soreness’, pp. 11-34, and McNamara and Ruys, 'Unlocking the Silences of the Self-Murdered', pp. 58-80.

${ }^{9}$ On the problems of psychiatric terminology when applied to female mysticism, see Hollywood, Sensible Ecstasy, especially pp. 243-245; and, more recently, Vuille,
} 
have stressed that acedia (the sin of sloth), tedia (weariness) and tristitia (sadness) are not 'precisely synonymous' with the modern medical condition, despite similarities. ${ }^{10}$ As observed by Stanley W. Jackson, the term 'depression' is a 'relative latecomer to the terminology for dejected states', coming into use primarily in the eighteenth and nineteenth centuries. ${ }^{11}$ In her work on glossing psychological distress in ancient Roman culture, Donatella Puliga also highlights the contribution of psychiatrist Emil Kraepelin (1856-1926) to the currency of this term. ${ }^{12}$ Modern-day clinical definitions of depression are both too restrictive and too expansive for our purposes:

a sign of psychiatric disorder or a component of various psychoses, with symptoms of misery, anguish, or guilt accompanied by headache, insomnia, etc[.]

a general slowing down of bodily and mental processes with what is usually termed a psychomotor retardation. ${ }^{13}$

'Maybe I’m Crazy? Diagnosis and Contextualization of Medieval Female Mystics’, pp. 103-121.

${ }^{10}$ The Book of Encouragement and Consolation, trans. by Otter, p. 80 n. 1; Walter Hilton: The Scale of Perfection, trans. by Clark \& Dorward, p. 170 n. 134.

${ }^{11}$ See Jackson, Melancholia and Depression, pp. 5-6 (p. 5 for quotation).

${ }^{12}$ Puliga, ‘Towards a Glossary of Depression’, p. 85, n. 9. For Krapelin’s work, see his 'Depressive States’ in The Nature of Melancholy, ed. by Radden, pp. 259-279; see further Radden’s introduction, pp. 3-51 (especially p. 16).

${ }^{13}$ First quotation from Oxford English Dictionary, definition 6b. Online: $<\underline{\text { http://www.oed.com }}>$ [accessed $3^{\text {rd }}$ October 2015]. Second quotation from Toohey, Melancholy, Love, and Time, p. 17. 
These definitions do not cover the range of affective states under the label 'anchoritic depression', nor are they sufficiently rooted in anchoritic practice.

The terms acedia, tedia, tristitia, and desperatio (despair) were generated through centuries of work on sin categorization: John Cassian (c. 360-435) and Gregory the Great (540-604) are two prominent sources of this vocabulary. ${ }^{14}$ Although initially distinguished from one another, acedia and tristitia gained semantic and conceptual closeness over time, particularly from the twelfth century onwards. ${ }^{15}$ But anchoritic depression cannot be reduced to acedia, tedia, tristitia, and desperatio alone. The phrase covers a wider spectrum of affective states associated with worldly sadness, spiritual disconsolation, and hopelessness in God's mercy; these include, but are not limited to, acedia in its post-twelfth-century sense of sinful sadness. ${ }^{16}$ None of these many conditions can be defined straightforwardly as an 'illness', but it is also clear that acedia was connected to the medical condition of melancholy as well as phlegmatic states in medieval humoral theory. ${ }^{17}$ As such, acedia and related conditions cannot be removed from a medical framework entirely. Despite its limitations, the term 'depression' does remain a useful shorthand for this spectrum of affective states.

\footnotetext{
${ }^{14}$ See further Wenzel, The Sin of Sloth, pp. 18-22 and pp. 22-28.

${ }^{15}$ See Wenzel, The Sin of Sloth, p. 25 and p. 52; and Bloomfield, The Seven Deadly Sins, p. 72.

${ }^{16}$ See further Wenzel, The Sin of Sloth, p. 60.

${ }^{17}$ See Bloomfield, The Seven Deadly Sins, p. 430 n. 61; Jackson, Melancholia and Depression, pp. 74-75; and Wenzel, The Sin of Sloth, pp. 191-194.
} 
As discussed by Wenzel and Peter Toohey, there is a deep-rooted literary tradition on spiritual 'depression’ in this broader sense. Cassian, most famously, dedicates the full tenth book of his Institutes to anchoritic acedia, and the ninth to the related condition of sadness (De Spiritu acediae; De Spiritu tristitiae). ${ }^{18}$ Accordingly, Toohey has challenged the notion that depression 'belongs to the modern world', a condition 'firmly based on the economic and labour conditions that have evolved since the Industrial Revolution and, before that, the Enlightenment' ${ }^{19}$ As mentioned, depression has particular resonance with the austere and sequestered anchoritic existence. $^{20}$

Entering the medieval period, depressive states become a source of concern in meditative texts - an important development given the centrality of meditation to anchoritic life. The depressive condition of lukewarm devotion (tepor, tepiditas) is an enduring anxiety in the Orationes sive meditationes (Prayers and Meditations) of Anselm of Canterbury (1033-1109), who, along with John of Fécamp, was a pioneer

\footnotetext{
${ }^{18}$ Iohannes Cassianus, De institutis coenobiorum et de octo principalium uitiorum remediis (Clavis Patrum Latinorum 513). See further Toohey, Melancholy, Love, and Time, pp. 139-149; and Berkeley, 'Jesus at the Age of Twelve', p. 31 n. 29.

19 Toohey, Melancholy, Love, and Time, p. 26.

${ }^{20}$ See further Toohey, Melancholy, Love, and Time, p. 138
} 
in solitary affective meditation. ${ }^{21}$ In Anselm's 'Prayer to Christ', the meditator prays for the Lord's strength to change his/her tepidity, requesting a metamorphosis:

Converte, misericordissime, meum teporem in ferventissimum tui amorem[.] ${ }^{22}$ (Turn, most merciful Lord, my tepidity into a most fervent love of you. $)^{23}$

Through the Lord's alchemical mercy, tepidity might be converted into fervent lovethe soul rustled out of its dullness. Towards the end of the 'Prayer for Friends', the speaker apologizes to the Lord for the 'tepid' prayer, a consequence of his/her frigid love ('Oratio pro amicis', 72). And in the third of Anselm’s famous trio of Marian prayers, designed to stir love, the meditator asks the Holy Mother to illuminate darkness, inflame tepidity, and awaken him/her from stupor:

illuminentur tenebrae meae, ut accendatur tepor meus, ut expergiscatur torpor meus $[\ldots]$

(let my darkness be illuminated, my tepidity be ignited, my numbness be awakened)

${ }^{21}$ See Southern, Saint Anselm: A Portrait in a Landscape, p. 102, and Saint Anselm and his Biographer: A Study of Monastic Life and Thought, pp. 38-39; see also The Prayers and Meditations of St. Anselm, trans. by Ward, p. 275.

${ }^{22}$ Orationes sive meditationes, ed. by Schmitt, III, p. 7; all subsequent references are to this edition.

${ }^{23}$ In order to maintain consistency in terminology, all translations are the author's own. 
Three conditions of spiritual retardation are each matched with a curative verb: darkness is illuminated (illuminare); tepidity is kindled or inflamed (accendere); and stupor is stirred, awakened (expergiscor). Through the Mother's activities within the soul, enabled by meditation, the speaker can feel love that is bright, warm, and alert.

For the Cistercian Bernard of Clairvaux (d. 1153), the focal point is not tepidity, but dryness. Dryness of heart is symptomatic of spiritual depression, as detailed in his ninth sermon in the Sermones super Cantica Canticorum: 'animi arentis languore atque hebetudine stolidae mentis' (dried soul in languour characterized by stupefied mind). ${ }^{24}$ This description follows citations of Psalms 142:6 and Psalm 19:4. ${ }^{25}$ The desiccated soul is placed in opposition to the breasts of the Canticles Bride, as the endless moisture of her chest comes from the flow of love from her insides ('semper abundant de visceribus caritatis, ut iterum fluant' (48)), supported by quotation of John 7:38. Toxic dryness is also explored in Bernard's fifty-fourth sermon on the Song of Songs, where he identifies the hills of Canticles 2:8 as the powers of the air which have fallen from pride, yet have failed to reach the lowness of the humble valleys. The Bridegroom leaps over these hills, damning the region to dryness and sterility ('ariditate ac sterilitate damnantur' (II, 104)).

Spiritual writers did not force these accounts of spiritual coldness and aridity without also offering remedies. The cures take both bodily and cognitive-affective

\footnotetext{
${ }^{24}$ Sancti Bernardi Opera, ed. by Leclercq, Talbot, and Rochais, I, p. 43; all subsequent references to Bernard's sermons are to this edition.

${ }^{25}$ Biblical references are to the Latin Vulgate and Douay-Rheims (Online), $<\underline{w w w . d r b o . o r g}>$ [accessed $4^{\text {th }}$ September 2016].
} 
forms, as is evident from the seventh century onwards. ${ }^{26}$ In particular, reading, prayer, and meditation are powerfully salvific. Benedicta Ward highlights the interconnection of these three activities in contemplative lives, also observed by Vincent Gillespie and Annie Sutherland. ${ }^{27}$ For an anchoress, reading the guidance texts becomes an act that palliates depressive symptoms; she gains restorative powers through her lectio divina, as is discernible in Liber confortatorius, De institutione inclusarum, and Ancrene Wisse.

\section{Tedia in Goscelin's Liber confortatorius}

The Liber confortatorius was written by Goscelin in the late eleventh century (c. 1082-83) for the anchoress Eva in Angers - known and loved by Goscelin during her time as a young nun in the abbey of Wilton. There is no evidence that Eva read it, however. ${ }^{28}$ Similarly to John Cassian, Goscelin dedicates the entire third book of his

${ }^{26}$ See Toohey’s useful summary of the prescribed remedies (Melancholy, Love, and Time, p. 138). The value of labour and more body-based remedies for acedia is evident in the Old Irish penitentials: see Medieval Handbooks of Penance: A Translation of the Principal Libri Poenitentiales, trans. by McNeill and Gamer, p. 168.

27 The Prayers and Meditations of St. Anselm, trans. by Ward, pp. 43-44; Gillespie, Looking in Holy Books, pp. 114-115; Sutherland, English Psalms in the Middle Ages, p. 20.

${ }^{28}$ On dating and readership of the text, and the provenance of its sole manuscript, see further The Book of Encouragement and Consolation, trans. by Otter, pp. 5-6; and 'The Liber confortatorius', ed. by Talbot, pp. 22-24. 
work to spiritual exhaustion, termed tedia. But he does not begin this book with dark depression. Instead, he opens with an iridescent description of Moses’ tabernacle based on Exodus 26:1:

Vniuersa machina ex bisso candidissimo constabat et purpura coccoque bis tincto aurosaque textura florebat. Vt omnium colorum, ita et omnium formarum pictura artificiosa decorem addiderat. [...] Tum aurea solis iocunditas perspicacissimum castrum quasi solidum ex omni colore uitero templum suis radiis perlustrabat, aurumque copiosissimum cunctarumque figurarum insigna suo lumine decorabat et uelut alterum celum perlucido tecto referebat, tum archam intus auream et aurea omnia diuinorum sacrorum utensilia clarificabat.

(The whole structure was made of the whitest linen, and it was adorned with purple fabric, twice-tinted scarlet, and gold embroidery. Masterful paintings of all colours and all forms added to the decoration. [...]. Then, the golden joy of the sun would shine its rays through this most translucent fortress, like a temple of solid glass in every colour; and with its light it would embellish the plentiful gold and the painted figures of all kinds, and reflect from the pellucid roof, as if from another sky. Then it would illuminate in gold the inside of the tabernacle and all the sacred utensils.)

As Goscelin clarifies to Eva, this tabernacle was not only for fleeting visual delight: it also provided solace ('solatia') when the Hebrews were alone and labouring in the 
desert ('longinque solitudinis labores et tedia leuigabat', 69). Goscelin’s writing appears to fulfill a similar purpose - his opulent illustration, far from being mere embellishment, is a form of consolation. Goscelin intends Eva to gain ocular pleasure from reading it, an act which would protect her from depression instigated by her own isolation and tedium.

Goscelin then applies the tabernacle directly to the cognitive process Eva should employ to heal her depression:

Sic tu igitur, o pignus meum dulce, si nec dum hereditariam uiuorum regionem mentis intrasti uigore, si oblitam petite patrie tedeat aliquando solitudinis, captiuitatis et clausule, erige tibi columnam fidei, tentorium spei, et quasi inde picto omni colore tabernaculo in lege Domini oblectare, exercitando et meditando in ea die ac nocte, cum sanctorum exemplorum multimodo decore.

(Therefore, you too, my sweet child, if with the strength of your mind you have not yet entered the land of the living; if sometimes you forget the homeland, wearied by your solitude, your captivity, and your enclosed space: build yourself a column of faith and a tent of hope, and as in a tabernacle painted in every colour, delight in the law of the Lord, exercising and meditating in it day and night, with the manifold decorations of the examples of the saints.)

With a mind nearing depression, she creates her own tabernacle through meditation, painted with spiritual colours and tools. This is a clear reference to the visual 
imagining she employs in her meditative practice, within Augustinian traditions. ${ }^{29}$ The 'eyes of her heart' enable Eva to overcome depression. ${ }^{30}$

As she meditates in her tabernacle, her cognitive process is outlined in precise steps:

Tum eternam claritatem eternamque noctem animo metire, tantaque spe uel timore tedia pelle.

(Measure in your soul the eternal brightness and the eternal night, and with that much hope and fear drive out depression.)

The immeasurable light and dark must nonetheless be 'measured' (metire), as this facilitates the crucial equipoise between hope and fear - a subject that will be returned to later in the context of Ancrene Wisse. After such measurement, intimacy with the Lord will become possible: 'Delectare in Domino, iam desines esse fa $<\mathrm{s}>$ tidiosa. Esto cum Domino, iam non eris solitaria’. (Delight in the Lord, and you will no longer be nauseated [or, exhausted]. Be with the Lord, and you will not be alone.) (69). Through his text, Goscelin nurtures Eva’s meditative strengths; there resides her spiritual weaponry.

${ }^{29}$ On the importance of vision in Augustine’s work, see Lootens, ‘Augustine’, pp. 5670 (especially pp. 57-58 and 60-61).

${ }^{30}$ On the tradition of the 'eyes of the heart', see Carruthers, The Book of Memory, p. 31. 
To avoid any blame being placed upon Eva, Goscelin voices depression not through her mouth, but through that of the loquacious devil: ${ }^{31}$

[.... qui tam sonora suadela sollicitet te: $<<$ Hec quid egisti? Quid tantos rerum splendores ab indole tua amputasti? Ah, uiridis uirgula a uernali gratia transplantata, ante tempus aruisti. Pupa es, adolescentula es, flos ipse uite repente peristi. An hic uicenna etatula in quinquagesimum uel centesimum sedebis annum, in senectam et senium, in finem longeuum et longinquum, in tam longos dies, tam profoundas noctes, in tam prolixos labores, tam iuges carceres, tam continuas desolationis mortes?>> (70)

([...] with that sonorous persuasion he solicits you: 'What have you done? Why have you cut off such splendid things from your self? Oh, verdant branch, transplanted from your vernal grace, you have withered before your time. You are a girl, an adolescent, the flower of life itself, and you have suddenly perished. From your tender age of twenty, will you sit until your fiftieth or hundredth year, in old age and elderly gloom, in a prolonged and distant end, in such long days, such profound nights, in such drawn-out labours, such perpetual prison, such continual deaths of desolation?)

${ }^{31}$ On Goscelin's view of Eva, see further Hayward, 'Representations of the Anchoritic Life in Goscelin of Saint-Bertin’s Liber confortatorius', pp. 54-64, and 'Spiritual Friendship and Gender Difference', pp. 341-353. 
We have precious insight here into what may have been common cognitive and affective stirrings among medieval anchorites. Her 'sudden death’ refers to her rite of enclosure, which included both the Office for the Dead and Extreme Unction. ${ }^{32}$ Although this ritual was considered cause for celebration, authors also recognized that the death-life of the anchorhold could be overwhelming. The endless consciousness of death, the deprivation of food and warmth, and the bareness of human contact- all may have oppressed the anchoress to the point of tedia.

From this basis, Goscelin progresses through a meditation on balancing life and death, citing biblical and classical authority to add credence to his words. Through his work, Eva's own cognitive balancing is effected:

Contra hos toruosi draconis flatus, cogita te cotidie transituram, semper tantum hodiernam, non crastinam, non longueam, omnem lucem tibi uenisse ultimam. Sic Oratius: Omnem crede diem tibi diluzisse supremum. (70)

(To counter these snorts of the tortuous dragon, think that you might cross over any day; always think that today's dawn is your last-not tomorrow's, not one in the distant future. As Horace says, Believe that each day that has dawned is your last.)

${ }^{32}$ On the rituals of enclosure, see Warren, Anchorites and their Patrons in Medieval England, pp. 98-99. 
Horace's assertion is then rooted in anchoritic practice, with thorough attention to the cell itself. ${ }^{33}$ As is typical of Goscelin's prose, he uses the collective wisdom of scripture, hagiography, and ‘pagan philosophy’ ('Phylosophia Ethnicorum’) to enrich his testimony on anchoritic living space. He addresses the horror the anchorite may feel in the confinement of her cell, linked to bodily sight (77). This is then expanded into a dualism of bodily and spiritual perception:

Es iste quidem sol presentialiter lucet omnibus, sed solis uidetur uidentibus. Quanto magis uerus sol iustitie Christus, semper inocciduus, semper adest omnibus, sed solis uidetur mundis cordibus, et pura fide eum intelligentibus. (77)

(The sun also shines in the presence of all, but is seen only by those who are able to see. How much more Christ, the true sun of justice, never sets, always present for all; but it can be discerned only by those with clean heart, and pure faith.)

His statement is buttressed by reference to Saint Omer and quotation of 'one of the responsories in an office for St Omer in the Breviary of St. Bertin’ (77). ${ }^{34}$ As visual delectability was used at the beginning of the book to initiate Eva's healing, so now is spiritual health made analogous with clear sight. To counter any distaste for her

${ }^{33}$ Horace, Epistles, Book I, Epistle IV (LOEB Classical Library 194: 276-277).

34 See The Book of Encouragement and Consolation, trans. by Otter, p. 91 ns 47 and 48. 
enclosure, the anchoress' own body and cell are offered up as the perfect living quarters:

Lapis puluinar, terra lectica, cilicium toga, crassa pellis frigori obuia, panis sobrius, pura legumina, vitrea unda cum munda conscientia Christique gratia[.]

(A stone is your couch, the ground your bed, a hair-shirt your garment; a thick skin keeps out the cold; your bread is healthy, your vegetables are pure, your water translucent, with your pure conscience and Christ's grace.)

Returning to the theme of depression-as-death, Goscelin does not deny anchoritic demise following her enclosure; he instead affirms the certainty of her resurrection:

Quid si te hic sepultam cogites, aut hoc cubiculum sepulcrum estimes? Ferendo crucem post Christum, de sepulcro resurges. Non nocet sepultura resurrecturis.

(You think of yourself as buried here, and deem your cell a grave? By carrying your cross after Christ, you will re-emerge from the tomb. Burial does not harm those who will rise again.) 
John 12: 24-25 and 2 Corinthians 6:9-10 are invoked to bolster his claim (79). He then again stresses the peril of being either too hopeful or too fearful, in a comment taken from the hymn 'Magnae Deus potentiae' for Thursday vespers, the service of evening prayer. ${ }^{35}$ With the hope of rebirth, Eva may stir away from deadly tedia.

The hymnal invocation enables Goscelin to move smoothly onto the vital role of prayer, scripture, and speech. He first invites Eva to celebrate the value of these soothing activities, with an echo of 1 Thessalonians 5:17:

Oratio et suspiria ad Deum sine intermissione et prout Dominus donauerit, lacrime uetant animam tedere.

(Prayers and sighs and tears to God, without intermission, prevent the soul from becoming wearied - as given by the Lord.)

For Goscelin, reading occurs subsequent to prayer; the activities are distinct and follow in stages:

Post debita orationum libamina, post deficientia lassitudine pectora, sancta lectione reficere, hebetatam mentem cote librorum exacue, decidentem flamme materiem inde adhibe.

${ }^{35}$ The Hymns of the Anglo-Saxon Church, ed. and trans. by Milfull, pp. 163-164 (ll. 13-16). 
(After you have given your offerings of prayers, after you are tired and exhausted within your breast, refresh yourself with sacred reading: sharpen your dulled mind with the whetstone of books, and from there supply the fading flame with wood.)

Eva can refresh herself (reficere) through sacred reading ('sancta lectione'). Repeated prayer has exhausted her, presumably because of its affective intensity. As a result, her mind has become dulled or deadened ('hebetatam mentem’), but through reading it can now be sharpened or stimulated (exacuer) and reignited ('decidentem flamme materiem inde adhibe') - a declaration lent support by quotation of Leviticus 6:12.

To offer more robust guidance, Goscelin shapes a specialized, medicinal reading programme for Eva, as has been traced by Gopa Roy. ${ }^{36}$ He advises her to consult the life of Desert Father Anthony ('uitam uero beati Antonii'), which must be read aloud (reciter). The use of this verb suggests that voiced reading is especially curative, though it should be remembered that such reading practice was customary for Goscelin and Eva. ${ }^{37}$ Our cleric of Saint-Bertin also highlights Augustine’s (354430) Confessiones for its stimulation to love:

Nec librum inter cetera postponas Augustini confessionum, qui tibi diuinum altius instillet affectum.

\footnotetext{
${ }^{36}$ Gopa Roy, “'Sharpen your Mind with the Whetstone of Books”, pp. 113-122.

${ }^{37}$ See The Book of Encouragement and Consolation, trans. by Otter, p. 96 n. 65.
} 
(Among all the others, do not neglect Augustine's Confessions, which will instill in you a higher affection for the divine.)

Given the pervasive influence of Augustine’s work on medieval psychological theory, it is not surprising that this text is honored. But even then, it is only part of a broader reading programme. Goscelin subsequently lists other texts, identifying in particular Eusebius’ (263-339) tripartite ecclesiastical history ('librum tripartitum ecclesiastice historie’), Augustine’s De Civitate Dei, Orosius’ (c. 375-c. 418) De Ormesta Mundi, and Boethius’ Consolation of Philosophy (c. 480-524) (80-81). He clarifies the rationale behind this selection: Eusebius’ history records the exemplarity of saints, and De Civitate Dei along with the work of Orosius and Boethius reveal the misery of worldly desire. Such a thorough reading regime cures any depression: 'His exercitiis terga dabunt tedia’ (With these exercises, depression will flee [or, surrender]). Her activity renders her time brief and her solitude sweet ('breuia uidebuntur tempora, et delectabit te solitudo tua'). Such is the potency of these texts that Goscelin's own exhortations will nauseate her ('iamque plena nausiabis insula hec hortamenta’ (81)). Whilst the guidance text itself has curative power, Goscelin wishes Eva to find healing beyond his work alone.

The reading regime leads onto further meditations on God's mercy, confinement, and the cosmology of the Creation, all of which can be activated through Eva's diligent reading and prayer (103-4, 106, 108). As this important book of the Liber confortatorius draws to a close, Goscelin controls the vagabond mind with nourishing communion. In the tender consumption of the Host, two bodies are bound, preventing seclusion from the Lord: 
Et qui dominico corpori et sanguini participatur, quid nisi Domino incorporatur, ut non solum spiritu, sed et corpore coniungatur? (90)

(And he who partakes of the Lord's body and blood, what is he incorporating except the Lord himself, so that he is conjoined to him not only in spirit but also in flesh?)

Anselm highlights tepidity at the start of his 'Prayer Before Receiving the Body and Blood of Christ', which implies that lukewarm devotion is dangerous when coinciding with the Eucharist (10). Equally, however, Goscelin shows that consumption of the wafer can itself heal a glacial soul. ${ }^{38}$ With invocation of 3 Kings 19:8, he portrays the Eucharistic wafer as integral to the healing concentration of the mind:

Tali cibo Christum cum sanctis angelis conuiuam habitura, nec foris mente uagabunda, sed intus cum Domino intenta, iam non eris solitaria, nec patieris mortalia tedia, sed in fortitudine cibi celestis transibis letabunda ad eterne pacis conuiuia.

\footnotetext{
${ }^{38}$ On the Side/Heart Wound as 'eucharistic [sic] medicine as revealed in the sacrament of the Mass', see Yoshikawa, 'Post-mortem Care of the Soul', pp. 159-160 and 165-166.
} 
(If you dine on such food together with Christ and his angels, with your mind not wandering outside but concentrated inwards on the Lord, you will not be alone, you will not endure deadly depression; but in the strength of heavenly food, you will cross over, rejoicing greatly, to the feast of eternal peace.)

A vagabond mind ('mente uagabunda') must be made still and secure. If her mind remains focused inwards on the intent of God (intus cum Domino intenta), Eva escapes the clutches of mortalia tedia. She consumes both text and body for this purpose. It is nourishment, of the most delectable and cherished sort, that will heal the lost and roaming soul.

\section{Tristitia and Acedia in Aelred's De institutione inclusarum}

Unlike Goscelin, the Cistercian abbot Aelred of Rievaulx does not dedicate a full section of his De institutione inclusarum to depression. It remains an abiding concern in his work, however, with the text acting as a remedy for his biological sister and other anchoritic readers or listeners. ${ }^{39}$ The first section, the Outer Man, includes explanations of worldly sadness and depression. The subsequent sections, the Inner Man and the Threefold Meditation, are preventative and curative through the anchoress' reading of them.

Aelred uses the terms tristitia and acedia, with acedia being a step further from the former. The identification of tristita as 'sadness' comes in the section on the

${ }^{39}$ On readership and transmission of the text, see further Millett, 'Women in No Man’s Land', p. 89; and Aelredi Rievallensis Opera Omnia: 1 Opera Ascetica, ed. by Hoste and Talbot, p. 637. 
Outer Man, when Aelred lays down the anchoress’ appropriate conversations. In her dialogue with a confessor, she may obtain counsel when in doubt and consolation when sad ('tristibus'): 'a quo consilium accipiat in dubiis, in tristibus consolationem' ${ }^{40}$ The identification of acedia occurs in the explanation of the anchoress' routine - again connecting the cure of acedia with the acts of reading and prayer, in addition to manual labour. Aelred embarks on a long criticism of idleness:

Otiositas quippe inimica est animae, quam prae omnibus cauere debet inclusa. Est enim omnium malorum parens, libidinis artifex, peruagationum altrix, nutrix uitiorum, formentum acediae, tristitiae incentiuum. Ipsa pessimas cogitationes seminat, affectiones illicitas creat, suscitat desideria. Ipsa quietis fastidium parit, horrorem incutit cellae. Nunquam proinde te nequam spiritus inueniat otioisam.

(Idleness is indeed the enemy of the soul, which above all others the recluse must beware. It is the parent of all evils, the master of passions, the fostermother of wanderlust, the nourisher of vice; it forms depression, encourages sadness. It is idleness which sows negative thoughts, creates illicit affections, stirs up desires. It is idleness which gives birth to weariness [or, disgust] with quiet, which instills horror of the cell. So never let the evil spirit find you idle.)

${ }^{40}$ De institutione inclusarum, in Aelredi Rievallensis Opera Omnia: 1 Opera Ascetica, ed. by Hoste and Talbot, p. 642; all subsequent references are to this edition. 
Like Goscelin, acedia involves the essential element of a restless mind or soul. In this grim passage, Aelred invokes the Rule of St Benedict in his statement on idleness as enemy of the soul, as does Goscelin (79); Jerome is behind the assertion that the spirit should never see the soul idle. ${ }^{41}$ Aelred clarifies the nature of 'acedia' and 'tristitia'. Along with negative thoughts ('pessimas cogitationes'), these states impel the soul to illicit desires ('affectiones illicitas creat'), and, as Goscelin also observed, causes the anchoress to become oppressed by her cell-based stagnancy. Aelred is concerned with giving lucid, practical instruction through the text to combat harmful acedia.

The term acedia is also employed in Aelred's treatise on the young Jesus, De Iesu Puero. As observed by Theodore Berkeley in his translation, acedia is 'a rather technical word in monastic spiritual writings'. ${ }^{42}$ The abbot's choice of term thus shows his desire for rigorous specificity - essential given the dangers associated with this state. As in his De institutione inclusarum, prayer to Christ is the salvation of the depressed soul:

Si igitur spiritus potestatem habens ascenderit super te, si stimulos acediae exagitauerit, si aculeos diuersarum passionum accenderit, si aduersus te commouerit mundum, si inflammauerit persecutiones, si times, si trepidas, si per singula momenta uinci formidabas et ita ad Iesum tuum anxius curris, ploras, exponis pericula, opem flagitatis, aderit tibi quem diligis, in specie regis potentisimi $[\ldots]$

\footnotetext{
${ }^{41}$ Benedictus de Nursia, Regula, chapter 48:1 (Clavis Patrum Latinorum 1852); and Jerome, Letter 125, section 11 (LOEB Classical Library 262: 416-417).

42 'Jesus at the Age of Twelve', trans. by Berkeley, p. 31 n. 29.
} 
(De Iesu Pvero, 270)

(If then a spirit with power rises up against you, if it harasses you with the spur of depression, if it kindles the thorn of diverse passions, if it provokes the world against you, if it inflames persecutions; if you are afraid, if you tremble, if for a single moment you fear that you will be vanquished - if you thus hurry to your Jesus in your anxiety, weeping, explaining the dangers, entreating his help, he whom you love will be there for you, as a most powerful king.)

The affective-cognitive stirrings of acedia are studied exhaustively: acedia involves weariness, temptation, a feeling of persecution, and overwhelming terror. Jesus comes as the balm for this downcast soul, and the passage is followed by the comforting citations of Psalm 34:2 and Jeremiah 1:8. Like De institutione inclusarum, this treatise offers meticulous explanation of acedia along with its remedies, so that the anchoress may heal herself when in need.

But more than this, De institutione inclusarum is itself a cure. The following sections of the anchoritic text - through elaboration of the inner soul and meditation on the past, present, and future - offer the anchoress a means of fighting her susceptibility to depression. This healing process is affirmed by Aelred himself at the end of the text:

[...] meditatio affectum excitet, affectus desiderium pariat, lacrymas desiderium excitet, ut sint tibi lacrymae tuae panes dies ac nocte, donec appareas in conspectu eius, et suscipiaris ab amplexibus eius, dicasque illud quod in Canticis scriptum est: Dilectus meus mihi et ego illi. 
([...] meditation will excite the affections, affections will give birth to desire, desire will excite tears, so that your tears can be bread for you day and night, until you appear in his sight, and supported by his embrace, say to him what is written in the Song of Songs: 'My beloved to me, and I to him.')

Two verbs are used to outline the meditative cure, with the pattern excitere (to excite, arouse, stir up), parire (to give birth to), and excitere again. A curve is formed, progressing from excitement, to birth, to excitement once more: it is a process of perpetual stimulation and renaissance. To strengthen his assertion, Aelred draws on the key biblical verses of Psalm 41:4 and Canticles 2:16. Although he does not refer to the Eucharistic wafer as explicitly as Goscelin does, the link of Psalm 41:4 to meditation suggests that this sacrament is crucial in treating spiritual dejection.

Meditation is not only reflected upon; it is also generated. The Passion component of Aelred's ‘threefold meditation’ has received attention elsewhere, though his meditation on the Nativity and the Afterlife are equally potent talismans against acedia. ${ }^{43}$ As Aelred's anchoress engages in the first meditative manoeuvre of turning to the past, she seeks the young Mary:

[...] ac primum cum beata Maria, ingressa cubiculum, libros quibus Virginis partus et Christi prophetatur aduentus euolue. Ibi aduentum angeli praestolare

${ }^{43}$ On the Passion sequence in Aelred's text, see Lazikani, Cultivating the Heart, pp. 16-17, 80, 90, 122-123. 
ut uideas intrantem, audias salutantem, et sic repleta stupore et extasi dulcissimam dominam tuam cum angelo salutante salutes, clamans et dicens: Aue, gratia plena, Dominus tecum, benedicta tu in mulieribus. (662-663)

(First enter the room of the blessed Mary, and with her read the books which foretell the virginal birth and the advent of Christ. There, wait for the coming of the angel so that you see him when he enters, hear him as gives the salutation, and thus filled with numbness and rapture, greet your most sweet lady with the angel. Cry out and say: 'Hail, full of grace, the Lord is with thee: blessed art thou among women.')

Meditation requires intimate involvement in the Saviour's birth - a remarkably healing activity. Before Gabriel's entrance, the anchoress is with Mary reading, the preposition 'cum' clarifying her participatory role. The anchoress sees the angel and chimes in with his greeting, based on Luke 1:28, thus voicing the Annunciation itself. In Judea with Mary and Elizabeth (Luke 1:39-45), she is again offered healing closeness to the scene, told to take part (admiscere) in the women's joy (663); she also becomes intimately involved on the journey to Bethlehem, and in the birth itself (663-664). In her involvement, the anchoress assumes soothing biblical voices: first of Gabriel, and then of Isaiah 9:6; when the child Jesus is lost at the temple, she hears and voices Mary's words at Luke 2:48 (664-665). Speaking these series of biblical 
voices during her Lover's birth and youth, she enables the healing touch of scripture to enter into herself. Through these inner voices, she can silence acedia with love. ${ }^{44}$

At the end of the meditation on the past, Aelred again observes how meditative activity may heal:

Haec omnia reuolue animo, ut in eum totus tuus resoluatur affectus. Vilescat tibi mundus, omnis amor carnalis sordescat. Nescias te esse in hoc mundo, quae ad illos qui in caelis sunt et Deo uiuunt, tuum transtulisti propositum. Vbi est thesaurus tuus, ibi sit et cor tuum. Noli cum argenteis simulacris uili marsupio tuo tuum includere animum, qui nunquam cum nummorum pondere poterit transuolare ad caelum.

(Revolve all this in your soul, so that your full affection may be released to him. Let the world become worthless to you, let all carnal love seem sordid. Become unaware that you are in this world, because you have transferred your way of life to those who are in the sky and live for God. For where thy treasure is, there is thy heart also. Do not imprison your soul with silver images in your worthless purse, for it will never be able to fly across to Heaven if it has the burden of coins.)

\footnotetext{
${ }^{44}$ On 'love' in Aelred’s corpus, see McGuire, Brother and Lover, especially pp. 7891; and, more recently, Rosenwein, Generations of Feeling, pp. 91-113.
} 
Through cognitive manoeuvering, the anchoress' affection is fully ('totus') with the Lord, disabling any spiritual weariness. Aelred speaks of the flight of the joyful soul; it is transported, with the author using verbs for transference and flight (transfere, transvolare). As meditation revolves within her (revolvere), she is transposed to a realm free of darkness - the citation of Matthew 6:21 encourages her flight. ${ }^{45}$ The anchoress is invited upwards; any depression weighing down her soul is removed, and she is lifted into the vast treasure-trove of Heaven. Aelred specifically warns of the weight of 'argenteis simulacris': this signifies the falseness of all worldly vanity, but also recalls his earlier distaste for a richly adorned cell (657). For a soul to be healed, it must discard all worthless weight.

After this comes the meditation on the future Afterlife. Aelred considers weariness again - but this time, as a means of liberation:

Si uita tua tibi oneri est, si mundus fastidio, si caro dolori, profecto desiderio tibi mors est, quae uitae huius onus deponit, finem ponit fastidio, corporis dolorem absumit.

(If your life is a burden to you, if you are weary of [or, feel disgust for] the world, if your flesh pains you, then surely death is a desire for you: to put away the burden of this life, to put an end to your weariness [or, loathing], to take away the body’s pain.)

\footnotetext{
${ }^{45}$ For the term 'revolve' as 'meditative, reflective', see further Roy, “" Sharpen your Mind with the Whetstone of Books”, p. 118.
} 
Such weariness is thus distinct from acedia, and is associated instead with yearning for God in the Gregorian sense of compunctio cordis (compunction of the heart). ${ }^{46}$ It is a weariness or disgust of life that propels the mind to celestial thought. Death lifts (deponere) all burdens, brings an end (ponere) to exhaustion, and takes away (absumere) bodily pain. These verbs evoke not only finality, but also completion and achievement. Thus fixed on the objective of the Afterlife, the soul is soothed from depression. Aelred uses world-weariness to combat weariness of the spirit. Freed from the silver images, the anchoress can take flight to celestial riches. This leads on to a meditation on Doomsday, with the ecstasy of Heaven and the terror of Hell juxtaposed - not an uncommon meditative technique. By meditating on both, fear and hope reach a healthy equilibrium, emphasized more than once by Goscelin. Such a balance is fundamental to the later Ancrene Wisse.

\section{Despair and Fear in Ancrene Wisse}

As is well known, Aelred's De institutione inclusarum is one of the named sources of Ancrene Wisse. This English text was written originally for three biological sisters, but it was later revised for a wider audience of anchoresses and adapted for male and lay readerships. ${ }^{47}$ This author's account of acedia comes in Part IV, the part dedicated to sins and temptations. Sloth, labelled with the French/Latin-derived 'accidie', is personified unusually as a bear - an analogy for which there is no clear

\footnotetext{
${ }^{46}$ See Leclercq, The Love of Learning and the Desire of God, trans. by Misrahi, p. 39.

${ }^{47}$ For an overview of its textual history, see Ancrene Wisse, ed. by Millett, II, pp. xxxvii-xl.
} 
epistemology. ${ }^{48}$ There is both a biblical and Augustinian precedent for bears as sinful, and even diabolical; these animals were perceived to have negative similarities with humanity, particularly in terms of their sexual behaviours. ${ }^{49}$ For this English author, like many Latin spiritual writers before him, the bear of acedia can be defined as deadly sorrow ('deadlich sar'). The deadly bear has eight cubs ('hwelpes'), all defined with clarity by the author. These include lukewarm devotion or 'torpor', witnessed earlier in Anselmian meditation, and idleness; the final child, 'the grimmest of alle', is despair (77-78).

After explaining sloth comprehensively, the Ancrene Wisse-author turns to its cure. As remarked by Sutherland, he unambiguously views reading and prayer as parts of one healing process: ${ }^{50}$

\footnotetext{
${ }^{48}$ See further Wenzel, The Sin of Sloth, p. 106. See also MED entries 'accidie (n.)' and 'slouthe (n.)'. For the unusual analogy of the scorpion in Ancrene Wisse, see Rumsey, ‘The Scorpion of Lechery’, pp. 48-58.

${ }^{49}$ See Pastoureau, Bestiaires du Moyen Âge, pp. 63 and 223 n. 4; and his The Bear: History of a Fallen King, trans. by Holoch, pp. 118 and 120. For instances of unpleasant bears in the Bible, see 1 Kings 17:34, 36, 37; 2 Kings 17:8; Proverbs 17: 12; Proverbs 28:15; Lamentations 3:10; Hosea 13:8; Revelation 13:2. In Augustine’s thirty-seventh sermon (on David, his father Jesse, and Goliath), the bear represents the devil (see $P L$ 39:1819 [accessed 25 $5^{\text {th }}$ September 2015]).

${ }^{50}$ Sutherland, English Psalms in the Middle Ages, p. 20.
} 
Accidies salue is gastelich gleadschipe ant froure of gleadful hope, purh redunge, purh hali poht, oðer of monnes muðe. Ofte, leoue sustren, 3e schulen uri leasse forte reden mare. Redunge is god bone.

(109: 1552-1554)

(The salve of acedia is spiritual joy and the comfort of joyful hope, through reading, through holy thought, or from man's mouth. Often, dear sisters, you should pray less in order to read more. Reading is good prayer.)

He uses the term 'salue', foregrounding the medical dimension to acedia. The curative salve for acedia stems from pleasant shifts of the soul, which are in turn nurtured by the acts of reading, thought, and hearing from 'man's mouth' - the latter presumably referring to preaching or confessional discussion. ${ }^{51}$ This resonates not only with Aelred, but also with Dominican William Peraldus’ (c. 1190-1271) cognitive-affective remedies for acedia in the later thirteenth century. ${ }^{52}$ Earlier in the

\footnotetext{
${ }^{51}$ This is supported by the gloss in the French translation of Ancrene Wisse ('par bone parole de bouche', p. 109 n. 35).

${ }^{52}$ Peraldus, Summa de vitiis, Treatise IX: 'De Acedia', in 'The Peraldus Project' (Online, 1995): < $\underline{\text { http://www.unc.edu/ Swenzel/peraldus.html }>}$ [accessed $4^{\text {th }}$
} September 2016]. For the full text, see Summa virtutum ac vitiorum: fols cxvi-cxvii for the remedies of acedia. Peraldus’ treatise was highly influential in the development of penitential literature and is thus important for gauging the broader climate, though it was produced later than the assumed date of Ancrene Wisse's composition. See further Gunn, Ancrene Wisse, p. 121; Amsler, Affective Literacies, p. 111; and Wenzel, The Sin of Sloth, pp. 75-77, 79-80, and 195-196. 
text, the Ancrene Wisse-author had again remarked that the comfort for acedia is 'redunge' - the only cardinal sin to be prescribed such medicine (see also 105: 1404). He demonstrates how reading cures acedia: 'Amidde pe redunge, hwen pe heorte likeð, kimeð up a deuotiun pet is wurð monie benen’ (While reading, when the heart is pleased, a devotion is stirred up that is worth many prayers), providing Jeromian authority for this statement (109). ${ }^{53}$ The later French translation of Ancrene Wisse glosses 'redunge’ with 'de Seint Escripture’ (of Holy Scripture), suggesting that the earlier English version keeps the nature of the anchoress’ reading open-ended (109 n. 34). Based on authorial comments elsewhere, her reading programme entailed Passion meditations and hagiographical writings, works which facilitate the spiritual gladness to which the author alludes (93).

The Ancrene Wisse-author remains, however, deeply concerned with the 'grimmest' spawn of acedia: 'unhope'. The struggle against despair is a serious matter in this text, evident in part by the author privileging an accessible vocabulary for his readers. His English term for despair, 'unhope', figures four times in the adapted version of the text in Cambridge, Corpus Christi College MS 402. ${ }^{54}$ In the Preface, it is invoked as a potent threat to the anchoress, regardless of her diligence.

\footnotetext{
${ }^{53}$ See further Amsler, Affective Literacies, p. 113. The Jeromian authority is from Jerome’s Letter 22 (LOEB Classical Library 262: 86-87).

${ }^{54}$ Concordance to Ancrene Wisse, ed. by Potts, Stevenson and Wogan-Browne, p. 807. In the MED, 'unhope' (n.) is defined as 'Lack of hope, despair', 'a state of despair', with two of its four citations from Ancrene Wisse and the related Sawles Warde.
} 
As mentioned earlier, the author does not wish the anchoress to make a vow to follow an Outer Rule, as this may throw her into despair:

[...] for as ofte as 3e prefter breken eni of ham, hit walde to swiðe hurten ower heorte ant makien ow swa offearet pet 3e mahten sone-pet Godd forbeode ow! - fallen i desesperance, pet is, in an unhope ant an unbileaue forte beon iborhen

(for as often as you thereafter break any of them, it would very much hurt your heart and make you so afraid that you might soon - may God forbid! - fall into despair, that is a lack of hope and lack of belief for having been born.)

He translates the uncommon noun 'desesperance' into 'an unhope ant an unbileaue forte beon iborhen'. ${ }^{55}$ It is the native term 'unhope', and not 'desesperance', that is chosen later in the text. Such a decision enables the anchoritic readers - many of whom throughout the text's history may have been unfamiliar with Latin terms - to confront this crucial infirmity. ${ }^{56}$

Notably, the author observes in this passage that 'unhope' comes from extreme fear ('makien ow swa offearet pet 3e mahten sone [...] fallen i

\footnotetext{
${ }^{55}$ For the few occurrences of this noun, see the $M E D$ entry 'desperaunce (n.)'.

${ }^{56}$ It should be noted, however, that Gunn and others have nuanced the 'popular view' that religious women enjoyed limited learning and literacy in Latin: see Gunn, Ancrene Wisse, p. 70. On anchoresses' literacy, see especially Millett, 'Women in No Man’s Land’, pp. 86-103; and Robertson, ““This Living Hand”, pp. 1-36.
} 
desesperance'). There is an intimate link in the anchoritic existence between the stirrings of despair and fear, though fear remains an underexplored emotion in medieval studies. ${ }^{57}$ This affective link made in Ancrene Wisse is still found in guidance literature a century later, in Walter Hilton’s (1340-1396) Scale of Perfection. In Book I, Chapter 37 ('Of divers temptaciouns of the feend of helle'), despair is tied with dread:

And therfore han thei than mykil sorwe, bothe for lakkynge of comfort and devocioun that thei weren wonte to have, and mykil drede of fallyng from God bi siche open synnes. ${ }^{58}$

After the solitary has been tempted, her or his 'mykil sorwe' is exacerbated not only by 'lakkynge of comfort and devocioun', but by the 'mykil drede' of fading from God's sight. Sorrow and dread become interdependent, both defined by their magnitude- 'mykil'. The counterpart section of Ancrene Wisse, Part IV, also connects fear with despair. As the most appalling whelp of the bear of 'hevi slawthe' (heavy sloth), 'unhope’ is connected with fear and loss of belief:

pis leaste beore hwelp is grimmest of alle, for hit tocheaweð ant tofret Godes milde milce ant his muchele mearci ant his unimete grace[.]

\footnotetext{
${ }^{57}$ For fear in other religious cultures, see Whitehouse, 'Rites of Terror: Emotion, Metaphor and Memory in Melanesian Initiation Cults’, pp. 133-148.

${ }^{58}$ The Scale of Perfection, ed. by Bestul, p. 70.
} 
(this last whelp of the bear is the grimmest of all, for it chews and tears to pieces God's gentle compassion, his great mercy, and his immeasurable grace[.])

Loss of God's sight and mercy is the source of fear, which in turn aggravates the despair following such a bereavement.

And yet, fear is foundational to the anchoritic vocation. In her earthly dwelling, the anchoress is oppressed by temptation or the threat of temptation; she purges herself of sin in confession only to accumulate more sin that must be purged once more in a repeating cycle of penitence. She lives in a state of constant anxiety, as described by Aelred:

Te, soror, nunquam uolo esse securam, sed timere semper, tuamque fragilitatem habere suspectam, et instar pauidae columbae frequentare riuos aquarum, et quasi in speculo accipitris cernere superuolantis effigiem, et cauere.

(I do not want you to ever be secure, sister, but to always be afraid. Be cautious of your frailties. Like the terrified dove, go to the streams of water; and, as in a mirror, see the image of the hawk flying overhead, and take care.) 
The anchoress chooses to become this ever-fearful dove, knowing that on earth she is only safe from the preying hawk when she is inside Christ's wounds, in anguish with Him. $^{59}$

Fear is not in itself a movement towards sin; it is, rather, a vital affective stirring. In the Ancrene Wisse author's elucidation of a confessant's self-examination in Part V, imaged as a judicial case, 'fearlac' (fear) is personified as a necessary jailguard; fear binds the penitent so that she/he may no longer sin (117). The author departs from Abelardian precepts in this instance by selecting fear, and not love, as the facilitator of 'Sorhe' (sorrow) behind 'bireowsunge' (contrition) ${ }^{60}$ In Sawles Warde, a text associated in textual history with Ancrene Wisse, the personified 'Fearlac' is one of the two essential messengers to the 'household' of the soul, enjoying equal status with 'Lufu' (love). ${ }^{61}$ Fear is also at the core of meditative practice. Anselm's 'Meditation 1' and his second prayer to Mary, for example, are both shaped to entice fear (timor): ‘Meditatio ad concitandum timorem’ and 'Oratio ad sanctam Mariam cum mens est sollicita timore'. The speaker of 'Meditation 1' reveals a slumbering and tepid soul, a state likened to a form of death (77); the speaker of the Marian meditation calls attention to the tepidity of his/her love ('tam tepida caritas mea', 17). It is fear, precipitated by these meditations, that can stir the soul out of depressive death.

\footnotetext{
${ }^{59}$ For this Bernardine image, see Sancti Bernardi Opera, II, p. 149.

${ }^{60}$ See Peter Abelard's Ethics, ed. by Luscombe, p. 84.

${ }^{61}$ See Sawles Warde, ed. by Wilson, pp. 4 and 8.
} 
Nonetheless, intense fear can escalate to the point of becoming unhealthy and even fatal to the soul. Fear should not breed despair, whether in an anchorite or a lay devotee. It is not surprising, therefore, that there is much material in thirteenthcentury confessional manuals on the need to reach a salutary mix of hope and fear, evident in the confessional section of Ancrene Wisse itself (see Part V, 126). An Anglo-Norman confessional manual found in Oxford, Bodleian Library, MS Douce 282, for example, defines compunction with a dual fear-hope model: 'Compunctiun aver sunt deus choses. Icestes sunt pour e esperance' (To have compunction is to have two things. These are fear and hope). ${ }^{62}$ Such a balance between hope and fear is especially germane to the anchoritic existence. In her work on early English devotional prose, Elizabeth Robertson assesses the anchoress' reading of Sawles Warde in her processes of affective regulation, and emphasizes the importance of the fear-hope combination. ${ }^{63}$ The Ancrene Wisse-author nurtures the anchoress' capacity to manage this affective balance - remaining in constant fear, yet standing far from the brink of 'unhope'.

The soul of the depressed anchorite is imaged as a dark, cold, and arid realm. As has been shown, 'spiritual depression' covers a range of conditions to which anchorites

62 'Cher alme': Texts of Anglo-Norman Piety, ed. by Hunt and trans. by Bliss, p. 296. The mid-thirteenth-century date of this manuscript suggests that the Ancrene Wisseauthor would not have used it directly, but it is an important example of vernacular confessional material during this period. See the comments by Hunt and Bliss, pp. 294-295.

${ }^{63}$ Robertson, Early English Devotional Prose, pp. 126-143. 
are acutely susceptible. The three guidance texts of the High Middle Ages investigated in this essay each offer not only explanation of these affective states, but also cures through the act of reading. For both Aelred and Goscelin, restlessness is at the core of spiritual depression. Yet, the authors develop two distinct taxonomies, a testament to the variety of definitions during this period: Goscelin's tedia versus Aelred's tristitia and acedia. Goscelin provides Eva with a rigorous reading cure whilst also demonstrating remedial cognitive techniques. Aelred gives his sister crystallized definitions of sadness and acedia, and displays the healing potential of meditation. For the Ancrene Wisse-author, acedia is also cured by reading and prayer. Its most terrible offspring, 'unhope’, must be prevented or treated through tempering the anchoress' fear; a wholesome mix of fear and hope keeps the bear's child at bay. As Toohey has remarked in a monastic context, it could be valuable to suffer a period of acedia, since the monk who survives such an ordeal 'grew immeasurably in strength'. ${ }^{64}$ This also resonates for the readers of the Liber confortatorius, De institutione inclusarum, and Ancrene Wisse: survivors may gain greater intimacy with the Lord. Once the festering layers of depression are peeled away, it is God who remains within. He dwells there to heal the broken of heart, and to bind up their bruises. ${ }^{65}$

\footnotetext{
${ }^{64}$ Toohey, Melancholy, Love, and Time, p. 138; see also Wenzel, The Sin of Sloth, p.

5.

65 See Psalm 146:3.
} 


\section{Bibliography}

\section{Primary Sources}

Abelard, Peter, Peter Abelard's Ethics: An Edition with Introduction, English Translation and Notes, ed. by David Edward Luscombe (Oxford: Clarendon Press, 1971).

Aelred of Rievaulx, De institutione inclusarum, in Aelredi Rievallensis Opera Omnia: 1 Opera Ascetica, ed. by Anselm Hoste and Charles H. Talbot, Corpus Christianorum Continuatio Mediaevalis, i (Turnhout: Brepols, 1971).

Ancrene Wisse: A Corrected Edition of the Text in Cambridge, Corpus Christi College, MS 402 with Variants from other Manuscripts, ed. by Bella Millett, 2 Vols, EETS O.S. 325 and 326 (London: Oxford University Press, 2005-2006).

Anselm of Canterbury, Orationes sive meditationes, in S. Anselmi Cantuariensis Archiepiscopi Opera Omnia, ed. by Franciscus Salesius Schmitt, 6 vols, III (Stuttgart: F. Frommann, 1968).

Augustine, $37^{\text {th }}$ sermon, in Patrologiae cursus completus: series Latina, ed. by J. P. Migne, 221 vols, 39 (Paris: Migne, 1844-55 and 1862-65): Patrologia Latina Database ((Online) Alexandria, VA, 1996).

Benedict of Nursia, Regula (Clavis Patrum Latinorum 1852), Library of Latin Texts: Series A (Online) (Turnhout: Brepols, 2010).

Bernard of Clairvaux. Sancti Bernardi Opera, 8 Vols, ed. by Jean Leclercq, Charles H. Talbot and Henri M. Rochais (Rome: Editiones Cistercienses, 1957-1977).

Cassian, John, De institutis coenobiorum et de octo principalium uitiorum remediis (Clavis Patrum Latinorum 513), Library of Latin Texts: Series A (Online) (Turnhout: Brepols, 2010).

'Cher alme': Texts of Anglo-Norman Piety, ed. by Tony Hunt and trans. by Jane Bliss (Tempe, AZ: Arizona Center for Medieval and Renaissance Studies, 2010).

Goscelin of Saint-Bertin, 'The Liber confortatorius of Goscelin of Saint-Bertin', ed. by Charles $\mathrm{H}$. Talbot, Analecta Monastica textes et études sur la vie des moines au moyen âge, 3me série, par M. M. Lebreton, Jean Leclercq, Orbis Catholicus (Rome: Herder, 1955).

Hilton, Walter, The Scale of Perfection, ed. by Thomas H. Bestul (Kalamazoo, MI: Medieval Institute Publications, 2000).

The Holy Bible, Douay Version: Translated from the Latin Vulgate (Douay, A. D. 1609: Rheims, A.D. 1582) (London: Catholic Truth Society, 1956) (Online, 20012016): <www.drbo.org $>$. 
Horace, Epistles, LOEB Classical Library (Online) (Cambridge, MA: Harvard University Press, 1911), 194.

The Hymns of the Anglo-Saxon Church: A Study and Edition of the 'Durham Hymnal', ed. and trans. by Inge B. Milfull (Cambridge: Cambridge University Press, 1996).

Jerome, Letters, LOEB Classical Library (Online) (Cambridge, MA: Harvard University Press, 1911).

Peraldus, William, Summa virtutum ac vitiorum (Paris, 1519).

Peraldus, William, 'The Peraldus Project', ed. by Kent Emery, Joe Goering, Richard Newhauser, and Siegfried Wenzel (Online, 1995):

$<$ http://www.unc.edu/ swenzel/peraldus.html $>$

Sawles Warde: An Early Middle English Homily Edited from the Bodley, Royal and Cotton MSS, ed. by Richard Middlewood Wilson (Kendal: Wilson, 1938).

Translations of Primary Sources

Aelred of Rievaulx, 'A Rule for the Life of a Recluse', trans. by Mary Paul Macpherson, in Treatises: the Pastoral Prayer, ed. by M. Basil Pennington (Kalamazoo, MI: Cistercian Publications, 1982). pp. 41-102.

Aelred of Rievaulx, 'Jesus at the Age of Twelve', trans. by Theodore Berkeley, in Treatises: the Pastoral Prayer, ed. by M. Basil Pennington (Kalamazoo, MI: Cistercian Publications, 1982). pp. 1-39.

Anselm of Canterbury, The Prayers and Meditations of St. Anselm, trans. by Benedicta Ward (Harmondsworth: Penguin, 1973).

Goscelin of St Bertin, The Book of Encouragement and Consolation, trans. by Monika Otter (Cambridge: D. S. Brewer, 2004).

Goscelin of St Bertin, Writing the Wilton Women: Goscelin's Legend of Edith and Liber confortatorius, ed. by Stephanie Hollis, with W.R. Barnes, Rebecca Hayward, Kathleen Loncar, and Michael Wright (Turnhout: Brepols, 2004).

Hilton, Walter, Walter Hilton: The Scale of Perfection, trans. by John P. H. Clark \& Rosemary Dorward (NY: Paulist Press, 1991).

Medieval Handbooks of Penance: A Translation of the Principal Libri Poenitentiales, trans. by John T. McNeill and Helena M. Gamer (NY: Columbia University Press, 1938; repr. 1990).

\section{Secondary Works}


Amsler, Mark, Affective Literacies: Writing and Multilingualism in the Late Middle Ages (Turnhout: Brepols, 2011).

Bloomfield, Morton W., The Seven Deadly Sins: An Introduction to the History of a Religious Concept, with Special Reference to Medieval English Literature (Michigan: State College Press, 1952).

Carruthers, Mary, The Book of Memory: A Study of Memory in Medieval Culture (Cambridge: Cambridge University Press, 1990).

Dekkers, Eligius and Emil Gaar, Clavis Patrum Latinorum: qua in novum Corpus christianorum edendum optimas quasque scriptorum recensiones a Tertulliano ad Bedam (Steenbrugis: In Abbatia Sancti Petri, 1961).

Dolan, Terence P. 'The Date of Ancrene Wisse: A Corroborative Note', Queries and Notes, 219 (1974), pp. 322-323.

Falconer, Rachel and Denis Renevey, eds. Medieval and Early Modern Literature, Science and Medicine (Tübingen: Narr Verlag, 2013).

Georgianna, Linda, The Solitary Self: Individuality in the Ancrene Wisse (Cambridge, MA: Harvard University Press, 1981).

Gillespie, Vincent, Looking in Holy Books: Essays on Late Medieval Religious Writing in England (Turnhout: Brepols, 2011).

Gunn, Cate, Ancrene Wisse: From Pastoral Literature to Vernacular Spirituality (Cardiff: University of Wales Press, 2008).

Hayward, Rebecca, 'Representations of the Anchoritic Life in Goscelin of SaintBertin's Liber confortatorius', in Anchorites, Wombs and Tombs, ed. by Liz Herbert McAvoy and Mari Hughes Edwards (Cardiff: University of Wales Press, 2005), pp. 54-64.

Hayward, Rebecca, 'Spiritual Friendship and Gender Difference', in Writing the Wilton Women: Goscelin's Legend of Edith and Liber confortatorius, ed. by Stephanie Hollis, with W.R. Barnes, Rebecca Hayward, Kathleen Loncar, and Michael Wright (Turnhout: Brepols, 2004), pp. 341-353.

Hollywood, Amy, Sensible Ecstasy: Mysticism, Sexual Difference, and the Demands of History (Chicago: University of Chicago Press, 2002).

Innes-Parker, Catherine, 'Ancrene Wisse and De Wohunge of Ure Lauerd: The Thirteenth-Century Female Reader and the Lover Knight', in Women, the Book and the Godly: Selected Proceedings of the St. Hilda's Conference, 1993, ed. by Lesley Smith and Jane H. M. Taylor (Cambridge: D. S. Brewer, 1995), pp. 137-148.

Jackson, Stanley W., Melancholia and Depression: From Hippocratic Times to Modern Times (New Haven: Yale University Press, 1986). 
Lazikani, Ayoush Sarmada, Cultivating the Heart: Feeling and Emotion in Twelfthand Thirteenth-Century Religious Texts (Cardiff: University of Wales Press, 2015).

Leclercq, Jean, The Love of Learning and the Desire for God, trans. by Catharine Misrahi (NY: Fordham University Press, 1961).

Lootens, Matthew R., 'Augustine’, in The Spiritual Senses: Perceiving God in Western Christianity, ed. by Paul Gavrilyuk, and Sarah Coakley (Cambridge: Cambridge University Press, 2012), pp. 56-70.

McAvoy, Liz Herbert, Medieval Anchoritisms: Gender, Space and the Solitary Life. (Woodbridge: D. S. Brewer, 2011).

McAvoy, Liz and Mari Hughes Edwards, eds. Anchorites, Wombs and Tombs (Cardiff: University of Wales Press, 2005).

McGuire, Brian Patrick, Brother and Lover: Aelred of Rievaulx (New York: Crossroad, 1994).

McNamara, Rebecca F., 'The Sorrow of Soreness: Infirmity and Suicide in Medieval England', Parergon 31.2 (2014), pp. 11-34.

McNamara, Rebecca and Juanita Ruys, 'Unlocking the Silences of the Self-Murdered: Textual Approaches to Suicidal Emotions in the Middle Ages', Exemplaria 26(1), pp. 58-80.

Middle English Dictionary, ed. by Hans Kurath and S. M. Kuhn (Ann Arbor: University of Michigan Press; London: Oxford University Press, 1952-) (Online), Michigan, 2001): < http://quod.lib.umich.edu/m/med/>.

Millett, Bella, 'Women in No Man's Land: English Recluses and the Development of Vernacular Literature in the Twelfth and Thirteenth Centuries', in Women and Literature in Britain 1150-1500, ed. by Carol M. Meale (Cambridge: Cambridge University Press, 1996), pp. 86-103.

Mulder-Bakker, Anneke B., Lives of the Anchoresses: The Rise of the Urban Recluse in Medieval Europe, trans. by Myra Heerspink Scholz (Philadelphia: University of Pennsylvania Press, 2005).

Oxford English Dictionary (Oxford: Oxford University Press, 1989, 1993, 1997) (Online): < $\underline{\text { http://www.oed.com }>\text {. }}$

Pastoureau, Michel, Bestiaires du Moyen Âge (Paris: Seuil, 2011).

Pastoureau, Michel, The Bear: History of a Fallen King, trans. George Holoch (Cambridge, Mass.: Belknap Press of Harvard University Press, 2011).

Potts, Jennifer, Lorna Stevenson and Jocelyn Wogan-Browne, eds, Concordance to Ancrene Wisse: MS Corpus Christi College Cambridge 402 (Cambridge: D. S. Brewer, 1993). 
Puliga, Donatella, 'Towards a Glossary of Depression and Psychological Distress in Ancient Roman Culture', in Infirmity in Antiquity and the Middle Ages: Social and Cultural Approaches to Health, Weakness, and Cure, ed. by Christian Krötzl, Katariina Mustakallio, and Jenni Kuuliala (Farnham: Ashgate, 2015), pp. 83-100.

Radden, Jennifer, ed., The Nature of Melancholy: From Aristotle to Kristeva (Oxford: Oxford University Press, 2000).

Robertson, Elizabeth, “"This Living Hand”: Thirteenth-Century Female Literacy, Materialist Immanence and the Reader of the Ancrene Wisse', Speculum 78, no. 1 (2003), pp. 1-36.

Robertson, Elizabeth, Early English Devotional Prose and the Female Audience (Knoxville: University of Tennessee Press, 1990).

Rosenwein, Barbara H., Generations of Feeling: A History of Emotions, 600-1700 (Cambridge: Cambridge University Press, 2016).

Roy, Gopa, “'Sharpen your Mind with the Whetstone of Books”: The Female Recluse as Reader in Goscelin's Liber confortatorius, Aelred of Rievaulx's De institutione inclusarum and the Ancrene Wisse', in Women, the Book and the Godly: Selected Proceedings of the St. Hilda's Conference, 1993, ed. by Lesley Smith and Jane H. M. Taylor (Cambridge: D. S. Brewer, 1995), pp. 113-122.

Rumsey, Lucinda, 'The Scorpion of Lechery and Ancrene Wisse', Medium Avum 61 (1992), pp. 48-58.

Southern, Richard William, Saint Anselm: A Portrait in a Landscape (Cambridge: Cambridge University Press, 1990).

Southern, Richard William, Saint Anselm and his Biographer: A Study of Monastic Life and Thought, 1059 - c. 1130 (Cambridge: Cambridge University Press, 1966).

Sutherland, Annie, English Psalms in the Middle Ages, 1300-1450 (Oxford: Oxford University Press, 2015).

Toohey, Peter, Melancholy, Love, and Time: Boundaries of the Self in Ancient Literature (Ann Arbor: University of Michigan Press, 2007).

Vuille, Juilette., 'Maybe I'm Crazy? Diagnosis and Contextualization of Medieval Female Mystics', in Medicine, Religion and Gender in Medieval Culture, ed. by Naoë Kukita Yoshikawa (Cambridge: D. S. Brewer, 2015), pp. 103-121.

Warren, Ann. K., Anchorites and their Patrons in Medieval England (Berkeley: University of California Press, 1985).

Wenzel, Siegfried, The Sin of Sloth: Acedia in Medieval Thought and Literature (Chapel Hill: The University of North Carolina Press, 1967). 
Whitehouse, Harvey, 'Rites of Terror: Emotion, Metaphor and Memory in

Melanesian Initiation Cults', Religion and Emotion: Approaches and Interpretations, ed. by John Corrigan (Oxford: Oxford University Press, 2004), pp. 133-148.

Yoshikawa, Naoë Kukita, 'Post-mortem Care of the Soul: Mechtild of Hackeborn's the Booke of Gostlye Grace', in Medieval and Early Modern Literature, Science and Medicine, ed. by Rachel Falconer and Denis Renevey (Tübingen: Narr Verlag, 2013), pp. 157-170.

Yoshikawa, Naoë Kukita, ed., Medicine, Religion and Gender in Medieval Culture (Cambridge: D. S. Brewer, 2015). 